\title{
Importance of NT-pro BNP in the Prevention of Heart Failure, Left Ventricular Systolic Dysfunction and Cardiovascular Events
}

\author{
Irina CUCIUREANU ${ }^{1,2}$, Cristian Alexandru ION 1,2, Anamaria-Georgiana AVRAM ${ }^{1,2}$,
} Maria Suzana GUBERNA ${ }^{1,2}$, Catalina Liliana ANDREI ${ }^{1,2}$, Crina-Julieta SINESCU ${ }^{1,2}$

\begin{abstract}
Objective: The importance of the NT-proBNP value in detecting patients at risk of developing heart failure (HF) and its importance in guiding medical management to prevent the development of HF. Material and methods: The study is a prospective study and includes 314 patients who was presented at the Bagdasar-Arseni Emergency Hospital for cardiology consultation, by appointment, for a period of 3 years. The inclusion criteria were as follows: essential hypertension (diagnosed more than 5 years before), diabetes mellitus (insulin-deficient or under treatment with oral ant diabetics diagnosed more than 5 years before), ischemic heart disease, mild or moderate valvulopathy (mild or moderate mitral regurgitation and large or moderate aortic stenosis) and permanent or paroxysmal atrial fibrillation. Exclusion criteria were as follows: a previous diagnosis of heart failure or left ventricular systolic dysfunction, and the presence of signs or symptoms of heart failure at the time of enrollment in the study. Patients were randomized into 2 groups, a control group and a intervention group. Patients in the intervention group were managed according to the NT-proBNP value, and patients in the control group received the conventional intervention. Patients were monitored for 3 years and the following objectives were pursued: new diagnosis of heart failure, systolic or diastolic dysfunction of the left ventricle and hospitalization for cardiovascular pathology. Results: After 3 years, in the control group there were 40 patients (25.5\%) who developed HF, compared to 28 patients (17.8\%) in the intervention group. In the control group, 60 patients (38.2\%) were diagnosed with left ventricular systolic dysfunction, compared to 43 patients $(27.4 \%)$ in the intervention group. Regarding left ventricular diastolic dysfunction, in the control group there were 98 patients (62.4\%), and in the intervention group there were 80 patients (51.0\%). Also, the rate of hospitalizations for cardiovascular pathology was higher in the control group, 56 patients (35.7\%), compared to 33 patients (21.0\%) in the intervention group. Discussions: The incidence of heart failure, left ventricular systolic or diastolic dysfunction, or hospitalizations for cardiovascular events, was lower in the intervention group, in which patients were managed according to the NT-proBNP value, compared to patients in the control group who received conventional intervention. Conclusions: The NT-proBNP biomarker may be useful in the medical management of patients for the prevention of heart failure
\end{abstract}

Keywords: prevention, heart failure, NT-proBNP.

\section{Rezumat}

Obiectiv: Relevanța valorii NT proBNP în depistarea pacienților la risc de a dezvolta insuficiență cardiacă (IC) și importanța lui în ghidarea managementul medical pentru a preveni dezvoltarea IC.Material și metode: Studiul este unul prospectiv și a inclus 314 pacienți care s-au prezentat la Spitalul de Urgență „Bagdasar-Arseni” pentru

${ }^{1}$ "Carol Davila" University of Medicine and Pharmacy, Bucharest, Romania

${ }^{2}$ Department of Cardiology, „Bagdasar-Arseni” Emergency

Clinical Hospital, Bucharest, Romania

\section{Corresponding author:}

Irina CUCIUREANU,180 Alunișului Street, Building no. 1, 2nd floor, apartment no. 137, 4th District, postal code: 040748, Bucharest, Romania.

E-mail: irinadimitriu@yahoo.com 
consult cardiologic, în regim programat, pe o perioada de 3 ani. Criteriile de includere au fost: hipertensiune arterială esentială (diagnosticată de peste 5 ani), diabet zaharat (insulino-necesitant sau în tratament cu antidiabetice orale diagnosticat de peste 5 ani), boală cardiacă ischemică, valvulopatii ușoare sau moderate (regurgitare mitrală ușoară sau moderată și stenoză aortică largă sau moderată) și fibrilație atrială permanentă sau paroxistică. Criteriile de excludere au fost diagnosticul anterior de insuficiență cardiacă sau disfuncție sistolică de ventricul stâng și prezența de semne sau simptome de insuficiență cardiacă la momentul inrolarii in studiu. Pacienții au fost randomizați în 2 grupuri, un grup de control și un grup de intervenție. Pacienții din grupul de intervenție au fost manageriați în funcție de valoarea NT proBNP, și pacienții din grupul de control au primit tratament standard. Pacienții au fost monitorizați 3 ani și au fost urmărite următoarele obiective: diagnostic nou de insuficiență cardiacă, disfuncția sistolică sau diastolică de ventricul stâng și spitalizarea pentru patologie cardiovasculară.Rezultate: După 3 ani, în grupul de control au fost 40 de pacienți (25,5\%) care au dezvoltat IC, comparativ cu 28 de pacienți (17,8\%) în grupul de intervenție. În grupul de control 60 de pacienți (38,2\%) au fost diagnosticați cu disfuncție sistolică de VS, comparativ cu 43 de pacienți $(27,4 \%)$ în grupul de intervenție. Cât privește disfuncția diastolică de VS, în grupul de control au fost 98 de pacienți (62,4\%), și în grupul de intervenție au fost 80 de pacienți (51,0\%). De asemenea, rata spitalizărilor pentru patologie cardiovasculară a fost mai mare în grupul de control, adică 56 de pacienți (35,7\%), față de 33 de pacienți $(21,0 \%)$ în grupul de intervenție. Discuții: Incidența insuficienței cardiace, a disfuncției sistolice sau diastolice de VS sau a spitalizărilor pentru evenimentele cardiovasculare a fost mai scăzută în grupul de intervenție, în care pacienții au fost manageriați în funcție de valoarea NT proBNP față de pacienții din grupul de control care au primit tratament standard. Concluzii: Biomarkerul NT proBNP poate fi util în managementul medical al pacienților pentru prevenția IC.

Cuvinte cheie: prevenție, insuficiența cardiacă, NT proBNP.

\section{INTRODUCTION}

Heart failure (HF) is a major public health issue worldwide. In Europe, about $1 \%$ of national health budgets are used to treat patients with heart failure ${ }^{1}$. In America, as well as in Romania, HF is the leading cause of hospitalization in patients over 65 years ${ }^{1,2}$. Heart failure is a condition that currently consumes a lot of money and imported resources for treatment, repeated hospitalizations, required surgeries or the management of complications.

In recent years, the prevalence and incidence of $\mathrm{HF}$ have been increasing and it is believed that this upward trend will continue ${ }^{3}$. Approximately $4.7 \%$ of the population over 35 in Romania suffers from $\mathrm{HF}$ and every hour 5 new cases of HF are diagnosed ${ }^{2}$. Currently, 64.3 million people worldwide suffer from $\mathrm{HF}$, the percentages varying between 1 and $4 \%{ }^{4,5}$, depending on the country.

Although many new therapies have been developed in recent years that have improved the prognosis in $\mathrm{HF}$, the mortality rate has remained high. A study conducted in Romania in 2018 showed that the standardized mortality rate due to chronic heart failure (HF) is 40 / 100,000 people $^{6}$. This is twice as high as in other Euro- pean Union countries. The Framingham study showed that after the diagnosis of heart failure, the survival rate after 1 year is $65 \%$, and after 5 years it is $25-30 \%{ }^{7}$.

In this context, in which the impact of HF is increased both on national health systems and on each individual patient, the HF prevention becomes paramount. Thus, various methods are sought for the early detection of persons at high risk of developing $\mathrm{HF}$ and the implementation of appropriate measures to prevent it ${ }^{8,9}$.

\section{OBJECTIVES}

The study aims to identify the use of an easy, safe and inexpensive method for detecting patients at risk of developing heart failure in the coming months or years. Patients in this risk group will be investigated and treated and this will prevent the onset of heart failure.

The proposed study method is to determine the value of NT-proBNP.

NT-proBNP (NT-pro-brain natriuretic peptide) is an important biomarker recommended by international guidelines for the diagnosis, monitoring of treatment and assessment of the prognosis in heart failure. The biomarker is widely used by medical test laboratories, but also by emergency services. 
The goal of this study is to determine the relevance of NT-proBNP determination in patients without heart failure, but with conditions that may develop into heart failure, to guide therapeutic conduct and prevention of $\mathrm{HF}$ or left ventricular (LV) systolic dysfunction.

\section{MATERIAL AND METHODS}

The study included patients who came to Bagdasar-Arseni Hospital for a cardiology consultation, by appointment, for three years. The inclusion criteria were as follows: essential hypertension (diagnosed more than 5 years before), diabetes mellitus (insulin-deficient or in treatment with oral antidiabetic drugs diagnosed more than 5 years before), ischemic heart disease, mild or moderate valvulopathy (mild or moderate mitral regurgitation and large or moderate aortic stenosis) and permanent or paroxysmal atrial fibrillation.

The exclusion criteria were as follows: previous diagnosis of heart failure or systolic dysfunction of the left ventricle, the presence of symptoms of heart failure at the time of the consultation and the refusal to participate in the study.

The study included 314 patients, who were randomized upon enrollment in 2 equal groups of 157 patients each: a control group and a intervention group.

The NT-proBNP value was determined in all patients at the time of enrollment. In the intervention group, patients were managed according to the NT-proBNP value, and in the control group patients received indications and conventional treatment of complaints for which they presented.

In the intervention group 86 patients had the NT-proBNP value $>125 \mathrm{pg} / \mathrm{dl}$. They were considered patients at risk of developing $\mathrm{HF}$, and were managed so as to try to prevent heart failure. They underwent a cardiac ultrasound and other necessary investigations, depending on the pathology of each case (exercise stress test, ECG Holter monitoring, BP Holter monitoring, coronary angiography). After completing a medical assessment as complex as possible, they received recommendations for lifestyle change, diet, medical, interventional or surgical intervention. Subsequently, the patients underwent regular cardiology consultations, with permanent adjustment of the therapeutic conduct.

Also, patients with a NT-proBNP value $<125 \mathrm{pg} /$ $\mathrm{dl}$ in the intervention group (71 patients) received indications and conventional intervention of complaints for which they presented.
Patients in the control group received indications and conventional intervention of complaints for which they presented, regardless of the NT-proBNP value.

Patients were monitored for 3 years and the following objectives were pursued:

- diagnosis of heart failure;

- left ventricular systolic dysfunction (defined as a decrease in ejection fraction below 50\%);

- left ventricular diastolic dysfunction;

- hospitalization for cardiovascular pathology (heart failure, acute coronary stroke, cerebrovascular accident or transient ischemic stroke, atrial fibrillation and pulmonary thromboembolism).

\section{RESULT}

The intervention group and the control group did not show statistically significant differences in terms of average age $(p=0.156)$, gender distribution $(p=0.258)$, and prevalence of smoking $(\mathrm{p}=0.221)$, dyslipidemia $(\mathrm{p}$ $=0.172)$, overweight and obesity $(\mathrm{p}=0.310)$, hypertension ( $p=0.231)$, diabetes mellitus $(p=0.103)$, ischemic heart disease $(p=0.649)$, a history of myocardial infarction $(\mathrm{p}=0.330)$, atrial fibrillation $(\mathrm{p}=0.705)$ and valvulopathies $(\mathrm{p}=0.333)$ (Table 1$)$.

Table 1. Characteristics of patients included in the research

\begin{tabular}{|l|l|l|l|}
\hline \multicolumn{1}{|c|}{ Characteristics } & $\begin{array}{c}\text { Intervention } \\
\text { group } \\
(\mathrm{N}=157)\end{array}$ & $\begin{array}{c}\text { Control } \\
\text { group } \\
(\mathrm{N}=157)\end{array}$ & $\begin{array}{c}\text { p } \\
\text { value }\end{array}$ \\
\hline Age (average \pm SD) & $67.79 \pm 6.18$ & $68.82 \pm 6.66$ & 0.156 \\
\hline Sex N (\%) & $79(50.3)$ & $89(56.7)$ & 0.258 \\
Male & $78(49.7)$ & $68(43.3)$ & \\
\hline Female & $53(33.8)$ & $43(27.4)$ & 0.221 \\
\hline Dyslipidemia N (\%) & $95(60.5)$ & $83(52.9)$ & 0.172 \\
\hline Overweight + obesity N (\%) & $74(47.1)$ & $83(52.9)$ & 0.310 \\
\hline Hypertension N (\%) & $141(89.8)$ & $134(85.4)$ & 0.231 \\
\hline Diabetes mellitus N (\%) & $52(33.1)$ & $66(42.0)$ & 0.103 \\
\hline Ischemia N (\%) & $70(44.6)$ & $66(42.0)$ & 0.649 \\
\hline Myocardial infarction N (\%) & $29(18.5)$ & $36(22.9)$ & 0.330 \\
\hline Atrial fibrillation N (\%) & $45(28.7)$ & $42(26.8)$ & 0.705 \\
\hline Valvulopathies N (\%) & $54(34.4)$ & $46(29.3)$ & 0.333 \\
\hline
\end{tabular}


The incidence of $\mathrm{HF}$ at 3 years was $17.8 \%$ (28 patients) in the intervention group and $25.5 \%$ (40 $\mathrm{pa}^{-}$ tients) in the control group, the difference being statistically insignificant $(p=0.100)$. Thus, the risk of HF onset at 3 years in the intervention group is insignificantly lower, compared to the risk of HF onset in the control group $(\mathrm{RR}=0.785 ;$ CI95\% $=0.577-1.068)$ (Table 2).

Table 2. Risk of HF

\begin{tabular}{|l|c|c|c|c|c|}
\hline \multirow{2}{*}{ Group } & \multicolumn{2}{|c|}{$\begin{array}{c}\text { HF (no. of } \\
\text { patients) }\end{array}$} & \multirow{2}{*}{ RR } & Cl 95\% & $\begin{array}{c}\text { p } \\
\text { value }\end{array}$ \\
\cline { 2 - 3 } & Yes & No & & & \\
\hline intervention & 28 & 129 & & & \\
\cline { 2 - 3 } control & 40 & 117 & 0.700 & $0.456-1.075$ & \multirow{2}{*}{0.100} \\
\hline \multirow{2yynn}{*}{ Total } & 68 & 246 & & & \\
\hline
\end{tabular}

The incidence of left ventricular (LV) systolic dysfunction at 3 years was $27.4 \%$ (43 patients) in the intervention group and $38.2 \%$ (60 patients) in the control group, the difference being statistically significant ( $p=0,0.41$ ). Thus, the risk of developing left ventricular systolic dysfunction at 3 years in the intervention group is significantly lower, compared to the risk of left ventricular systolic dysfunction in the control group $(\mathrm{RR}=0.773 ; 95 \% \mathrm{CI}=0.596-1.002)($ Table 3$)$.

Table 3. Risk of left ventricular systolic dysfunction

\begin{tabular}{|l|r|r|r|r|c|}
\hline \multirow{2}{*}{ Group } & \multicolumn{2}{|c|}{$\begin{array}{c}\text { Left ventricular } \\
\text { systolic } \\
\text { dysfunction } \\
\text { (no. of } \\
\text { patients) }\end{array}$} & RR & Cl 95\% & p \\
\cline { 2 - 3 } & Yes & No & & \\
\hline intervention & 43 & 114 & & \multirow{2}{*}{$0.519-$} & \\
\cline { 2 - 3 } control & 60 & 97 & 0.717 & 0.990 & $\mathbf{0 . 0 4 1}$ \\
\hline Total & 103 & 211 & & & \\
\hline
\end{tabular}

The incidence of left ventricular diastolic dysfunction at 3 years was $51.0 \%$ ( 80 patients) in the intervention group and $62.4 \%$ (98 patients) in the control group, the difference being statistically significant $(\mathrm{p}=$
0.040). Thus, the risk of developing left ventricular diastolic dysfunction at 3 years in the intervention group is significantly lower, compared to the risk of developing left ventricular diastolic dysfunction in the control group $(\mathrm{RR}=0.794 ;$ CI95\% = 0.638-0.988) $($ Table 4$)$.

Table 4. Risk of left ventricular diastolic dysfunction

\begin{tabular}{|c|c|c|c|c|c|}
\hline \multirow[t]{2}{*}{ Group } & \multicolumn{2}{|c|}{$\begin{array}{c}\text { Left } \\
\text { ventricular } \\
\text { diastolic } \\
\text { dysfunction } \\
\text { (no. of } \\
\text { patients) } \\
\end{array}$} & \multirow[t]{2}{*}{$\mathbf{R R}$} & \multirow[t]{2}{*}{ CI 95\% } & \multirow[t]{2}{*}{$p$ value } \\
\hline & Yes & No & & & \\
\hline intervention & 80 & 77 & \multirow{3}{*}{0.816} & \multirow{3}{*}{$0.671-0.993$} & \multirow{3}{*}{0.040} \\
\hline control & 98 & 59 & & & \\
\hline Total & 178 & 136 & & & \\
\hline
\end{tabular}

The incidence of hospitalizations for cardiovascular pathology at 3 years was $21.0 \%$ (33 patients) in the intervention group and $35.7 \%$ (56 patients) in the control group, the difference being statistically significant $(p=0.004)$. Thus, the risk of hospitalizations for cardiovascular pathology at 3 years in the intervention group is significantly lower, compared to the risk of hospitalizations in the control group $(\mathrm{RR}=0.673 ; 95 \%$ $\mathrm{CI}=0.501-0.904)($ Table 5).

Table 5. The risk of hospitalization for cardiovascular pathology

\begin{tabular}{|c|c|c|c|c|c|}
\hline \multirow[t]{2}{*}{ Group } & \multicolumn{2}{|c|}{$\begin{array}{l}\text { Hospitalization } \\
\text { for } \\
\text { cardiovascular } \\
\text { pathology } \\
\text { (no. of } \\
\text { patients) }\end{array}$} & \multirow[t]{2}{*}{$\mathbf{R R}$} & \multirow[t]{2}{*}{$\mathrm{Cl} 95 \%$} & \multirow[t]{2}{*}{$\begin{array}{c}\mathrm{p} \\
\text { value }\end{array}$} \\
\hline & Yes & No & & & \\
\hline intervention & 33 & 124 & \multirow{3}{*}{0.589} & \multirow{3}{*}{$0.407-0.852$} & \multirow{3}{*}{0.004} \\
\hline control & 56 & 101 & & & \\
\hline Total & 89 & 225 & & & \\
\hline
\end{tabular}

The main reasons for hospitalizations for cardiovascular pathology during 3 years are: atrial fibrillation (11.5\% in the control group and $6.4 \%$ in the intervention group), stroke (8.9\% in the control group and $5.7 \%$ 


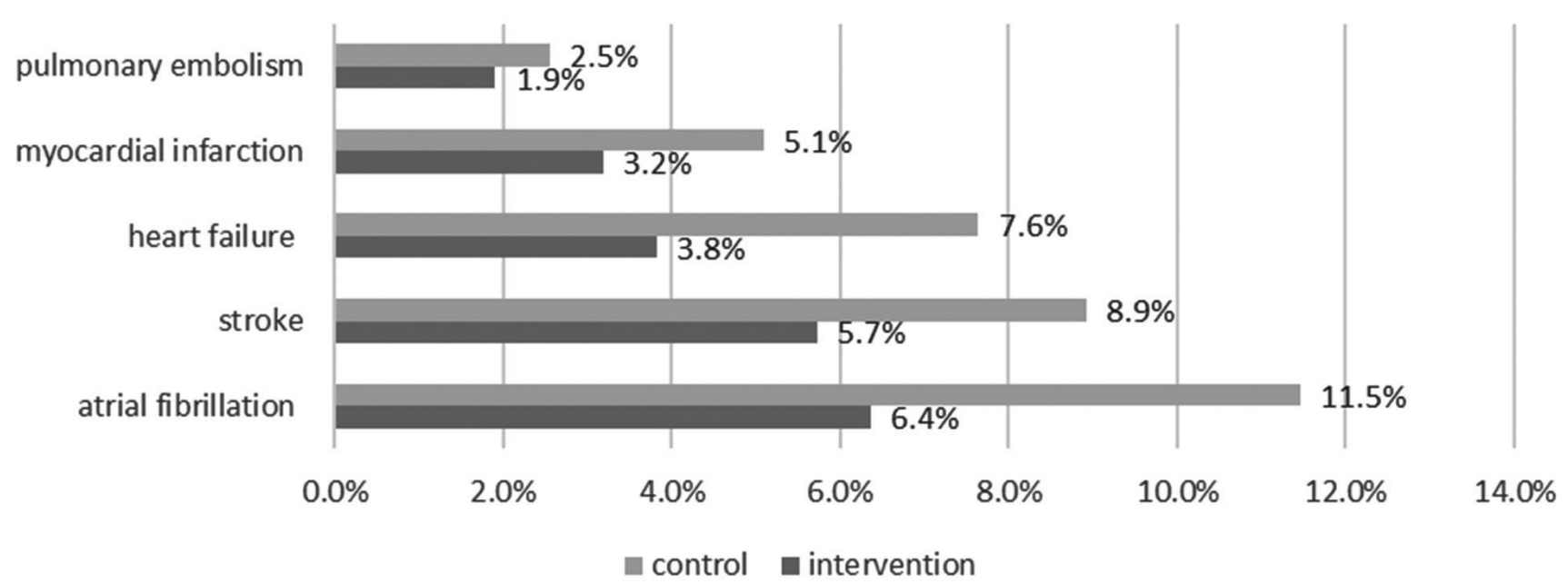

Figure 5. The reasons for hospitalizations for cardiovascular pathology for 3 years depending on the intervention administered

in the intervention group) and heart failure (7.6\% in the control group and $3.8 \%$ in the intervention group) (Figure 5).

\section{DISCUSSIONS}

Statistical data processing showed that in the intervention group, in which patients were managed according to the NT-proBNP value, the incidence of heart failure, left ventricular systolic or diastolic dysfunction, or hospitalizations for cardiovascular events, was lower than in patients in the control group.

In our study, NT-proBNP has been used in patients without heart failure, but with conditions that put patients at risk of developing heart failure. The management of these patients at risk of developing $\mathrm{HF}$ was guided by the value of NT-proBNP. Thus, the therapeutic conduct guided by the value of NT-proBNP reduced the incidence of $\mathrm{HF}$, left ventricular systolic or diastolic dysfunction, and reduced the rate of hospitalizations for cardiovascular pathology.

The literature does not provide much evidence on the relevance of the NT-proBNP biomarker in preventing or delaying the onset of $\mathrm{HF}$ and in guiding the management of patients at risk. There is only one study in Dublin, Ireland that investigated the role of natriuretic peptides in the prevention of $\mathrm{HF}$ and left ventricular dysfunction. The study enrolled 1374 patients who were monitored for 4 years. This study showed that the determination of natriuretic peptides (BNP) level can be a good screening method for people with cardiovascular disease and that the management of these patients can be guided by the value of NT-proBNP ${ }^{10}$. However, the literature includes more evidence regarding the prognostic value of natriuretic peptides. A study by Kistorp C. on 764 adults without cardiovascular disease at the time of enrollment in the study showed that after 5 years of monitoring, elevated NT-proBNP levels were correlated with a higher mortality rate and an increased risk of developing the first cardiovascular event. The conclusion was, in terms of mortality and cardiovascular events, the NT-proBNP biomarker is a more important prognostic factor than traditional cardiovascular risk factors ${ }^{11}$.

Also, the Framingham Heart Study, which evaluated 3346 patients over 5 years, showed that patients' risk of developing HF, cardiovascular events, and death was correlated with elevated BNP / NT-proBNP values ${ }^{12,13}$.

The conclusion of studies on this topic is that plasma levels of natriuretic peptides (BNP / NT-proBNP) can be used in patients without $\mathrm{HF}^{14,15}$, being an important predictor of the risk of developing $\mathrm{HF}$ or other cardiovascular events.

The strengths of the study would be that: it is a prospective study, which enrolled a large number of patients, who were monitored for a relatively long period of time. The theme of the paper is an ongoing concern, namely cardiovascular prevention, and more specifically, the prevention of heart failure. Prevention of heart failure is an extremely current issue, with epidemiological trends showing that in the USA, in 2030, 30\% of the population will suffer from heart failure ${ }^{16,17}$.

Among the limitations of the study, we mention that this is a unicentric study, performed on the pa- 
tient population in a university center. The situation may vary across the country, especially in areas where the population has limited access to medical services. The concept of screening and prevention measures is more difficult to implement in these areas. Although the duration of patient monitoring was relatively long, it should be borne in mind that the objectives of the study, namely: the occurrence of heart failure or left ventricular dysfunction, are complications that occur over a long period of time. In view of this, the 3-year follow-up of patients with vascular risk factors may be insufficient for the development of HF or impaired left ventricle function.

\section{CONCLUSIONS}

The conclusion of the study is that the NT-proBNP biomarker is useful in detecting patients at risk of developing heart failure, and also the management of these patients, guided by the value of NT-proBNP, and

\section{References}

1. McMurray JJ, Adamopoulos S, Anker SD, Auricchio A, Böhm M, Dickstein K, Falk V, Filippatos G, Fonseca C, Gomez-Sanchez MA, Jaarsma T, Køber L, Lip GY, Maggioni AP, Parkhomenko A, Pieske BM, Popescu BA, Rønnevik PK, Rutten FH, Schwitter J, Seferovic P, Stepinska J, Trindade PT, Voors AA, Zannad F, Zeiher A; ESC Committee for Practice Guidelines. ESC Guidelines for the diagnosis and treatment of acute and chronic heart failure 2012: The Task Force for the Diagnosis and Treatment of Acute and Chronic Heart Failure 2012 of the European Society of Cardiology. Developed în collaboration with the Heart Failure Association (HFA) of the ESC. Eur Heart J. 2012 Jul;33(14):1787-847.

2. Ovidiu Chioncel, Gabriel Tatu-Chitoiu, Ruxandra Christodorescu, at all. Characteristics of patients with heart failure from Romania enrolled în - ESC-HF Long-Term (ESC-HF-LT) Registry. Romanian Journal of Cardiology, 2015, Vol. 25, No. 4

3. Hunt SA, Abraham WT, Chin MH, Feldman AM, Francis GS, Ganiats TG, Jessup M, Konstam MA, Mancini DM, Michl K, Oates JA, Rahko PS, Silver MA, Stevenson LW, Yancy CW. 2009 focused update incorporated into the ACC/AHA 2005 Guidelines for the Diagnosis and Management of Heart Failure în Adults: a report of the American College of Cardiology Foundation/American Heart Association Task Force on Practice Guidelines: developed în collaboration with the International Society for Heart and Lung Transplantation. Circulation. 2009 Apr 14;119(14):e391-479.

4. GBD 2017 Disease and Injury Incidence and Prevalence Collaborators. Global, regional, and national incidence, prevalence, and years lived with disability for 354 diseases and injuries for 195 countries and territories, 1990-2017: a systematic analysis for the Global Burden of Disease Study 2017. Lancet. 2018 Nov 10;392(10159):1789-1858. can prevent: left ventricular systolic dysfunction, hospitalizations for cardiovascular disease and heart failure.

Determining the value of NT-proBNP is an easy, fast and inexpensive method and can be used in the future in screening patients with cardiovascular disease to prevent heart failure.

Compliance with ethics requirements: The authors declare no conflict of interest regarding this article. The authors declare that all the procedures and experiments of this study respect the ethical standards in the Helsinki Declaration of 1975, as revised in 2008(5), as well as the national law. Informed consent was obtained from all the patients included in the study.
5. Groenewegen A, Rutten FH, Mosterd A, Hoes AW. Epidemiology of heart failure. Eur J Heart Fail. 2020 Aug;22(8):1342-1356.

6. Dorobantu M, Tautu OF, Dimulescu D, Sinescu C, Gusbeth-Tatomir P, Arsenescu-Georgescu C, Mitu F, Lighezan D, Pop C, Babes K, Giuca A, Branza I, Udrescu M, Herdea V, Darabont R. Perspectives on hypertension's prevalence, treatment and control în a high cardiovascular risk East European country: data from the SEPHAR III survey. J Hypertens. 2018 Mar;36(3):690-700.

7. Hunt SA, Abraham WT, Chin MH, Feldman AM, Francis GS, Ganiats TG, Jessup M, Konstam MA, Mancini DM, Michl K, Oates JA, Rahko PS, Silver MA, Stevenson LW, Yancy CW. 2009 focused update incorporated into the ACC/AHA 2005 Guidelines for the Diagnosis and Management of Heart Failure în Adults: a report of the American College of Cardiology Foundation/American Heart Association Task Force on Practice Guidelines: developed în collaboration with the International Society for Heart and Lung Transplantation. Circulation. 2009 Apr 14;119(14):e391-479.

8. Groenewegen A, Rutten FH, Mosterd A, Hoes AW. Epidemiology of heart failure. Eur J Heart Fail. 2020 Aug;22(8):1342-1356.

9. Alehagen $U$, Dahlström U, Rehfeld JF, Goetze JP. Association of copeptin and $\mathrm{N}$-terminal proBNP concentrations with risk of cardiovascular death în older patients with symptoms of heart failure. JAMA. 2011 May 25;305(20):2088-95.

10. Ledwidge M, Gallagher J, Conlon C, Tallon E, O'Connell E, Dawkins I, Watson C, O'Hanlon R, Bermingham M, Patle A, Badabhagni MR, Murtagh G, Voon V, Tilson L, Barry M, McDonald L, Maurer B, McDonald K. Natriuretic peptide-based screening and collaborative care for heart failure: the STOP-HF randomized trial. JAMA. 2013 Jul 3;310(1):66-74.

11. Kistorp C, Raymond I, Pedersen F, Gustafsson F, Faber J, Hilde- 
brandt P. N-terminal pro-brain natriuretic peptide, C-reactive protein, and urinary albumin levels as predictors of mortality and cardiovascular events în older adults. JAMA. 2005 Apr 6;293(13):1609-16.

12. Wang TJ, Larson MG, Levy D, Benjamin EJ, Leip EP, Omland T, Wolf PA, Vasan RS. Plasma natriuretic peptide levels and the risk of cardiovascular events and death. N Engl J Med. 2004 Feb 12;350(7):655-63.

13. Mahmood SS, Levy D, Vasan RS, Wang TJ. The Framingham Heart Study and the epidemiology of cardiovascular disease: a historical perspective. Lancet. 2014 Mar 15;383(9921):999-1008.

14. Bayes-Genis A, Lupón J, Jaffe AS. Can Natriuretic Peptides be Used to Guide Therapy? EJIFCC. 2016 Aug 1;27(3):208-16.

15. Luers C, Wachter R, Kleta S, Uhlir M, Koschack J, Scherer M, Binder L, Herrmann-Lingen C, Zapf A, Kulle B, Kochen MM, Pieske B. Natriuretic peptides în the detection of preclinical diastolic or systolic dysfunction. Clin Res Cardiol. 2010 Apr;99(4):217-26.

16. Steinhart B, Thorpe KE, Bayoumi AM, Moe G, Januzzi JL Jr, Mazer $\mathrm{CD}$. Improving the diagnosis of acute heart failure using a validated prediction model. J Am Coll Cardiol. 2009 Oct 13;54(16):1515-21.
17. Heidenreich PA, Trogdon JG, Khavjou OA, Butler J, Dracup K, Ezekowitz MD, Finkelstein EA, Hong Y, Johnston SC, Khera A, LloydJones DM, Nelson SA, Nichol G, Orenstein D, Wilson PW, Woo YJ; American Heart Association Advocacy Coordinating Committee; Stroke Council; Council on Cardiovascular Radiology and Intervention; Council on Clinical Cardiology; Council on Epidemiology and Prevention; Council on Arteriosclerosis; Thrombosis and Vascular Biology; Council on Cardiopulmonary; Critical Care; Perioperative and Resuscitation; Council on Cardiovascular Nursing; Council on the Kidney în Cardiovascular Disease; Council on Cardiovascular Surgery and Anesthesia, and Interdisciplinary Council on Quality of Care and Outcomes Research. Forecasting the future of cardiovascular disease în the United States: a policy statement from the American Heart Association. Circulation. 2011 Mar 1;123(8):933-44. 